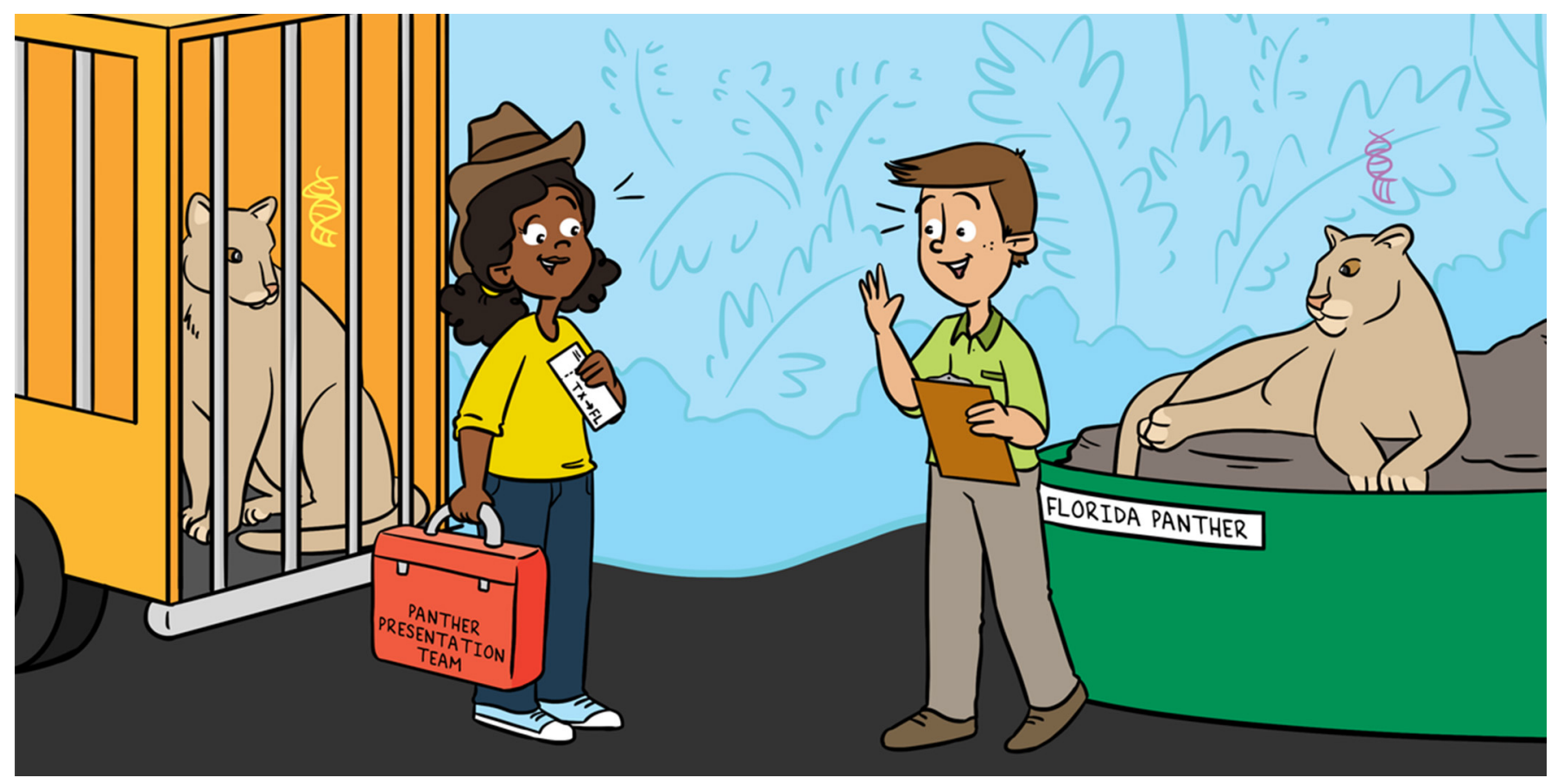

\title{
WHAT IS GENETIC DIVERSITY AND WHY DOES IT MATTER?
}

\author{
Melissa Minter ${ }^{1 \neq \neq}$, Erica S. Nielsen ${ }^{2 \dagger}$, Colette Blyth ${ }^{3 \neq}$, Laura D. Bertola ${ }^{4 \neq \$}$, Michael Benjamin Kantar ${ }^{5}$, \\ Hernán E. Morales ${ }^{6}$, Chloé Orland ${ }^{7}$, Gernot Segelbacher ${ }^{8 \$}$ and Deborah M. Leigh ${ }^{9 * \$}$ \\ ${ }^{1}$ Department of Biology, University of York, York, United Kingdom \\ ${ }^{2}$ Evolutionary Genomics Group, Department of Botany and Zoology, University of Stellenbosch, Matieland, South Africa \\ ${ }^{3}$ School of Biological Sciences, University of Adelaide, North Terrace, SA, Australia \\ ${ }^{4}$ Department of Biology, University of Copenhagen, Copenhagen, Denmark \\ ${ }^{5}$ Department of Tropical Plant and Soil Sciences, University of Hawai'i, Honolulu, HI, United States \\ ${ }^{6}$ Section for Evolutionary Genomics, GLOBE Institute, University of Copenhagen, Copenhagen, Denmark \\ ${ }^{7}$ Department of Ecology and Evolutionary Biology, University of California, Santa Cruz, Santa Cruz, CA, United States \\ ${ }^{8}$ Wildlife Ecology and Management, University Freiburg, Freiburg, Germany \\ ${ }^{9}$ Biodiversity and Conservation Biology, Swiss Federal Research Institute for Forest, Snow and Landscape Research WSL, \\ Birmensdorf, Switzerland
}

YOUNG REVIEWER:

ALY

AGE: 13
All living things on Earth contain a unique code within them, called DNA. DNA is organised into genes, similar to the way letters are organised into words. Genes give our bodies instructions on how to function. However, the exact DNA code is different even between individuals within the same species. We call this genetic diversity. Genetic diversity causes differences in the shape of bird beaks, in the flavours of tomatoes, and even in the colour of your hair! Genetic diversity is important because it gives species a better chance of survival. However, genetic diversity can be lost when populations 
GENE

A section of DNA that contains the instructions for a trait.

\section{GENETIC DIVERSITY}

The overall diversity in the DNA between the individuals of a species.

\section{MUTATION}

A change in an organism's DNA. This can be a change of a single letter or a much bigger change of hundreds of letters at once. get smaller and isolated, which decreases a species' ability to adapt and survive. In this article, we explore the importance of genetic diversity, discuss how it is formed and maintained in wild populations, how it is lost and why that is dangerous, and what we can do to conserve it.

\section{WHY IS EVERYTHING AND EVERYONE A LITTLE BIT DIFFERENT?}

Earth contains millions of different species that all look different from one another. While some species look more similar to each other than others, like lions and tigers, they will still have differences between them. Even within each species, individuals look similar to each other but they are not identical. These differences and similarities are because of many small differences between individuals' genes. All organisms have DNA and each individual's DNA is organised into genes. These contain the instructions to build our bodies. This is similar to the way that letters are combined to make words that then make a story. DNA can be seen as the letters, genes the words, and their instructions are the story. Small differences in DNA might change blue eyes to green, or a butterfly's wings from black to white, like how a word can change when you replace a letter.

The combined differences in the DNA of all individuals in a species make up the genetic diversity of that species. Genetic diversity causes individuals to have different characteristics, which we can see even in our groceries. Although all tomatoes belong to the same species, the tomatoes we eat are hugely diverse, ranging from giant beefeater tomatoes to tiny cherry tomatoes. There are also hundreds of apple varieties (Figure 1), that range from red to green, tart to sweet, and some apples even have pink flesh inside! Genetic diversity is what makes these types of tomatoes and apples look so different [1]. Genetic diversity is also seen in animals. For example, dogs can be large enough to pull sledges or small enough to sit nicely on your lap. All dogs are from the same species, but they look different because of genetic diversity! Though often more difficult to see, genetic diversity is also extremely important in wild animals and plants.

\section{HOW IS GENETIC DIVERSITY GENERATED?}

Changes to an individual's DNA are called mutations (Figure 2). Mutations can arise when mistakes are made while cells are copying DNA, like making a spelling mistake when copying a word. These mutations make up a species' genetic diversity. Over generations, more and more mistakes are made, leading to more mutations. Most mutations are either harmful or have no impact at all, but sometimes these mutations can cause changes that are helpful for a species. The individuals that have these helpful mutations might have greater chances of survival, and have more babies as a result [2]. This is 


\section{Figure 1}

An example of genetic diversity in the food we eat. All these apples are one species. Different alleles of the genes that control their colour cause the apples to be green, yellow, red, or almost purple. Differences in the alleles that control flavour make each type taste different.

\section{ADAPTATION}

The process of a species changing in order to better survive in its environment.

\section{ALLELES}

Different variations of a gene caused by mutations. Many species have two alleles for every gene, one copy from each parent.

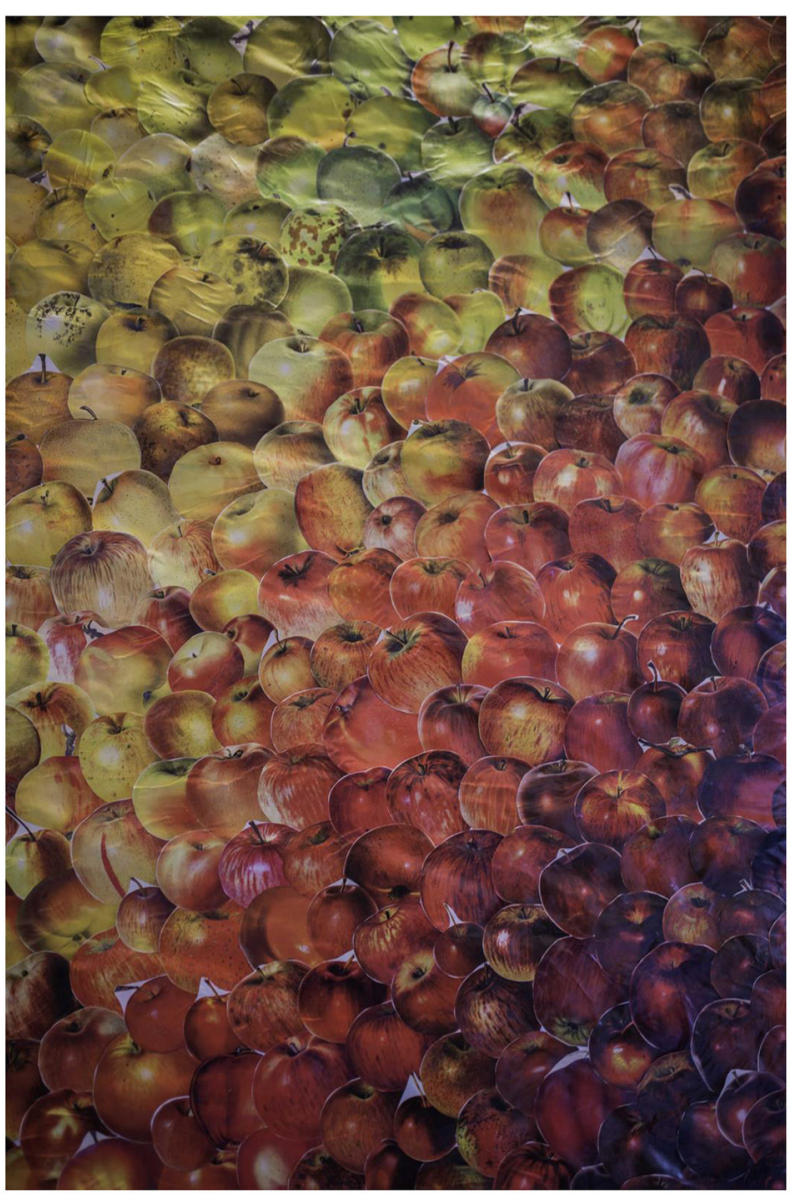

Figure 1

adaptation. When a mother and a father have babies, the DNA of their baby is a mix of the parents' DNA. Babies have two copies of every gene in their DNA, one from each parent. Copies of the same gene with different mutations are called alleles. When parents make a sperm or an egg, alleles in each parent are shuffled and recombined, and only one allele of a gene ends up in each sperm or egg cell. When the reshuffled alleles from a mother and a father are combined when sperm and eggs join, new mixes of alleles are created in the babies $[2,3]$. The mixing of alleles allows for new combinations of mutations and characteristics, adding to a species' genetic diversity (Figure 2).

Not all species need a mother and a father to make a baby. Bacteria can clone themselves (Figure 2) and directly pass their alleles from a parent to its identical clone [3]. Any mistakes in the parent's DNA will be passed on to the clone. Amazingly, bacteria can also give alleles to each other, even if they are not related! This is a unique way simple species like bacteria can increase their genetic diversity, without relying on the mixing of alleles between a mother and a father [4]. 
Figure 2

(A) Genetic diversity is generated when mutations create new alleles over time. Mixing alleles from parents creates new combinations of alleles in their babies.

Organisms that can clone themselves, like bacteria, can pass alleles to each other. Each coloured dot represents a different allele. (B) Genetic diversity can be lost when habitat loss divides populations or when buildings or highways isolate populations. (C) Creating protected areas where individuals from different populations can migrate and spread their genes can help a species to maintain its genetic diversity.
A. Generation
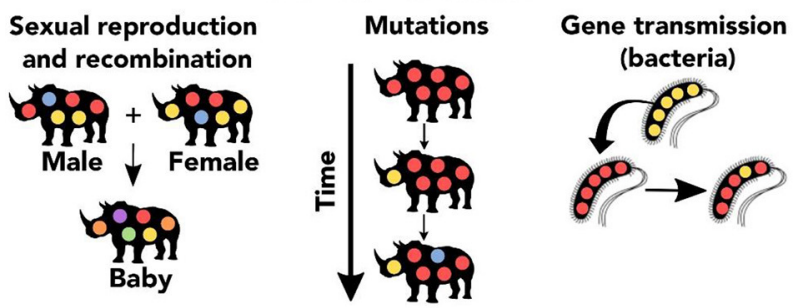

B. Loss

Reduced population size

and habitat fragmentation

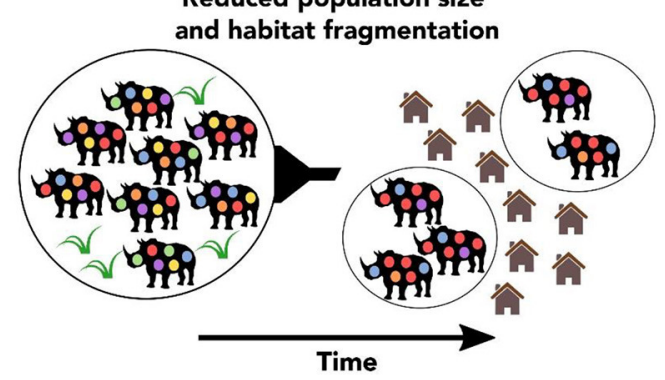

C. Maintenance

Nature reserve

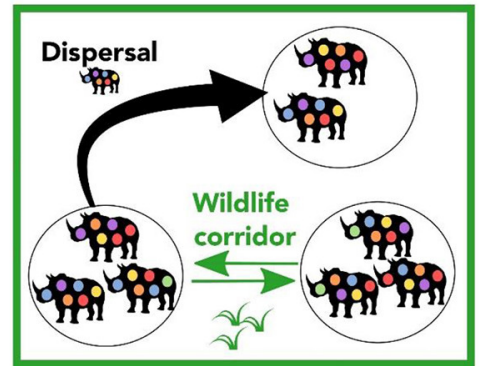

Figure 2

\section{WHY IS GENETIC DIVERSITY IMPORTANT?}

When a species has a lot of differences in its DNA, we say that genetic diversity is high [2]. In species with high genetic diversity, there are lots of mutations in the DNA, which cause differences in the way individuals look as well as differences in important traits that we cannot see [2]. This is called adaptation. For example, some types of apples can grow better in hotter environments, thanks to their genes. The variety of characteristics in species with high genetic diversity means they are more likely to successfully cope with changes in their environment. A great example of this is seen in the peppered moths during the industrial revolution [4]. Natural genetic diversity in peppered moths produced different wing colours, ranging from light to dark. Before the Industrial Revolution, peppered moths with light wings were more common because they had the best camouflage on white tree trunks. The Industrial Revolution caused a lot of air pollution that started to cover tree trunks, making them black. Light-winged moths were no longer camouflaged and were easy prey for birds. But dark-winged individuals were now hidden! This meant that dark moths had an 


\section{INBREEDING}

Breeding between closely related individuals. Inbreeding often happens when populations are small and there are few options for mating. Inbred individuals are usually less healthy.

\section{INBREEDING}

DEPRESSION

Inbred individuals share ancestors and are more likely to have identical copies of genes. If these genes contain harmful mutations, they will be expressed and cause lower health of inbred individuals.

\section{GENETIC RESCUE}

A conservation strategy, new individuals are moved into a population to increase genetic diversity and improve population health. advantage and were more likely to live long enough to have babies. The babies of dark moths were also dark because of the alleles they inherited from their parents, so they were also more likely to survive. The dark moths had higher fitness and became more common as a result [4].

\section{WHAT HAPPENS WHEN GENETIC DIVERSITY IS LOW?}

When few mutations are found in the DNA of a species, genetic diversity is said to be low [2]. Low genetic diversity means that there is a limited variety of alleles for genes within that species and so there are not many differences between individuals. This can mean that there are fewer opportunities to adapt to environmental changes. Low genetic diversity often occurs due to habitat loss. For example, when a species' habitat is destroyed or broken up into small pieces, populations become small. Small, fragmented populations can lead to loss of genetic diversity because fewer individuals can survive in the remaining habitat so fewer individuals breed to pass on their alleles. In small populations, the choice of mates is also limited. Over time, individuals will all become related and will be forced to mate with relatives. This is inbreeding. Inbred animals often have two identical alleles for their genes because the same gene was passed on from both parents. If this allele has harmful mutations, an inbred baby can be unhealthy. This is called inbreeding depression [2].

If genetic diversity gets too low, species can go extinct and be lost forever. This is due to the combined effects of inbreeding depression and failure to adapt to change. In such cases, the introduction of new alleles can save a population. This is called genetic rescue [2]. In the 1990s conservation scientists had to use genetic rescue to save the Florida panther, which was threatened by extinction due to low genetic diversity (Figure 3) [5]. Very few Florida panthers remained and their genetic diversity was extremely low. Many Florida panther babies were sick because of inbreeding depression. A closely related panther with high genetic diversity was present in Texas. Texan panthers were moved to Florida to have babies with the Florida panthers. This increased genetic diversity because of the mixing of alleles we spoke about before. Soon after the Texan panthers arrived, many healthy kittens were born [5].

\section{WHAT'S HAPPENING TO GENETIC DIVERSITY AROUND THE WORLD?}

We hear a lot about the loss of species in the world, but we are also seeing a loss of genetic diversity within species. The increasing number of people on Earth and our increasing use of natural resources has reduced space and resources for wild species. Over time, many wild animal and plant populations have become smaller or more isolated. 
Figure 3

(A) The Florida panther was once widespread, with high genetic diversity. (B) Hunting and habitat loss reduced population size and resulted in very low genetic diversity and inbreeding. (C) Eight female panthers from Texas were moved to Florida to breed with Florida panthers. (D) When the Texas and Florida panthers bred, new alleles were introduced into the population, helping the Florida panther population become bigger and healthier over time.

\section{A Florida panther population becomes fragmented}

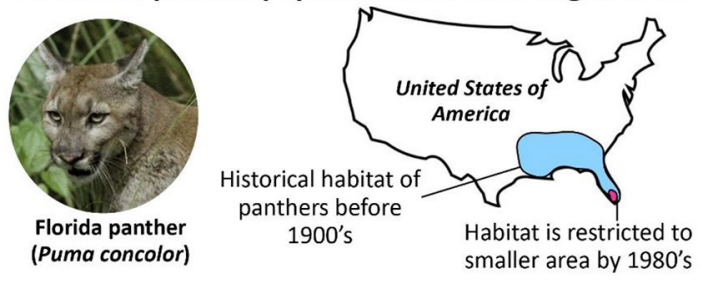

\section{B Population decline leads to inbreeding}

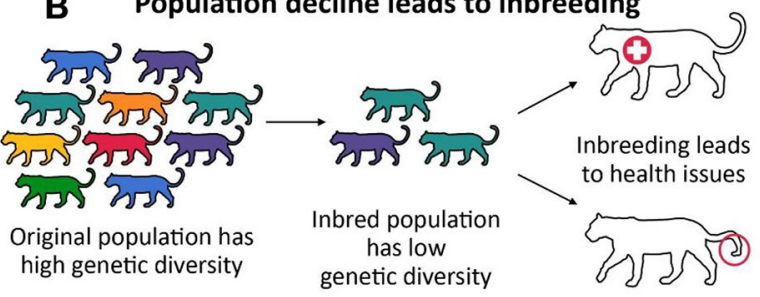

C Genetic rescue with Texas panther genes

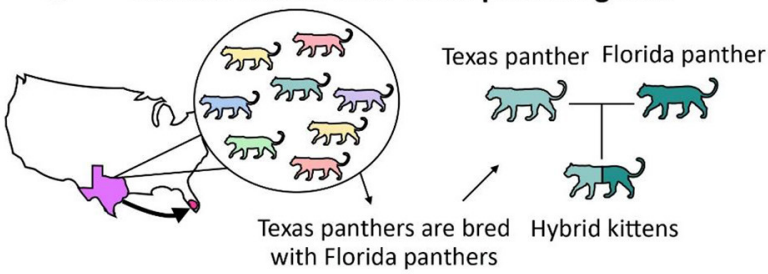

D Genetic diversity increases in hybrid population
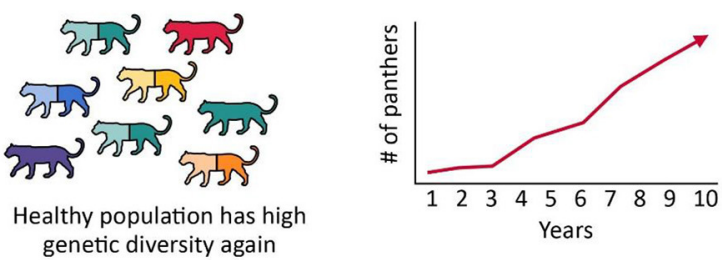

Figure 3

Many species have also gone through local extinctions. This has led to a global loss of genetic diversity. Scientists think that the genetic diversity within species may have declined by as much as $6 \%$ globally since the Industrial Revolution [6]. This means that many species are less able to adapt when facing new challenges, like climate change, pollution, and new diseases. If too much genetic diversity is lost, more and more species could become unhealthy and in need of conservation actions similar to the Florida panther. However, there are steps we can take to conserve and restore genetic diversity across many species.

\section{HOW DO WE STOP GENETIC DIVERSITY LOSS?}

We must preserve and protect genetic diversity. This can be done through the conservation of our remaining wild populations [2]. We can use nature reserves and wildlife bridges to reconnect wild populations that have become separated by our cities and highways. 
We can also restore habitats, because this will allow wild populations to get bigger. Sometimes we can even remove harmful stressors and pests so that populations can naturally regrow. We can also reintroduce species that have been lost from habitats they used to live in. Taken together, these strategies can help stop genetic diversity loss. It is important to protect genetic diversity because it is the foundation for healthy species. Healthy species are necessary for human health and for the health of the whole planet!

\section{REFERENCES}

1. Meyer, R., and Purugganan, M. 2013. Evolution of crop species: genetics of domestication and diversification. Nat. Rev. Genet. 14:840-52. doi: $10.1038 / \mathrm{nrg} 3605$

2. Frankham, R., Ballou, J. D., and Briscoe, D. A. 2002. Introduction to Conservation Genetics. Cambridge: Cambridge University Press. p. 617

3. Emamalipour M., Seidi K., Zununi V. S., Jahanban-Esfahlan A., Jaymand M., Majdi H., et al. 2020. Horizontal gene transfer: from evolutionary flexibility to disease progression. Front. Cell. Dev. Biol. 8:229. doi: 10.3389/fcell.2020.00229

4. Cook, L. M., and Saccheri, I. J. 2013. The peppered moth and industrial melanism: evolution of a natural selection case study. Heredity 110:207-12. doi: 10.1038/hdy.2012.92

5. Johnson, W. E., Onorato, D. P., Roelke, M. E., Land, E. D., Cunningham, M., Belden, R. C., et al. 2010. Genetic restoration of the Florida panther. Science 329:1641-5. doi: 10.1126/science.1192891

6. Leigh, D. M., Hendry, A. P., Vázquez-Domínguez, E., and Friesen, V. L. 2019. Estimated six per cent loss of genetic variation in wild populations since the industrial revolution. Evol. Appl. 12:1505-12. doi: 10.1111/eva.12810

SUBMITTED: 20 January 2021; ACCEPTED: 12 November 2021; PUBLISHED ONLINE: 09 December 2021.

\section{EDITED BY: Didone Frigerio, University of Vienna, Austria}

CITATION: Minter M, Nielsen ES, Blyth C, Bertola LD, Kantar MB, Morales HE, Orland C, Segelbacher G and Leigh DM (2021) What Is Genetic Diversity and Why Does it Matter? Front. Young Minds 9:656168. doi: 10.3389/frym.2021.656168

CONFLICT OF INTEREST: The authors declare that the research was conducted in the absence of any commercial or financial relationships that could be construed as a potential conflict of interest.

COPYRIGHT () 2021 Minter, Nielsen, Blyth, Bertola, Kantar, Morales, Orland, Segelbacher and Leigh. This is an open-access article distributed under the terms of the Creative Commons Attribution License (CC BY). The use, distribution or reproduction in other forums is permitted, provided the original author(s) and the copyright owner(s) are credited and that the original publication in this journal is cited, in accordance with accepted academic practice. No use, distribution or reproduction is permitted which does not comply with these terms. 

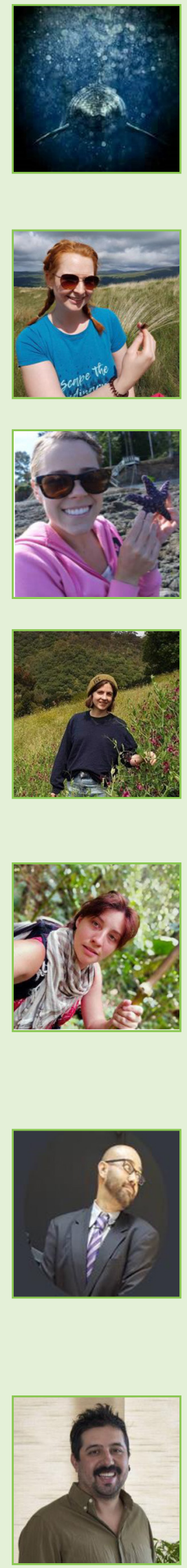

\section{YOUNG REVIEWER}

\section{ALY, AGE: 13}

I am Aly, and I am interested in Biology, Palaeontology, and reading about animals and their behaviour. I like lizards, sharks, and bears!

\section{AUTHORS}

\section{MELISSA MINTER}

Melissa Minter is a Ph.D. researcher at the University of York, United Kingdom. Her research focuses on how past, present, and future climate change impact the genetics of a mountain butterfly, and how this translates into conservation. She is interested in all things genetics, conservation, and insects!

\section{ERICA S. NIELSEN}

Erica Nielsen is a Ph.D. researcher at Stellenbosch University, South Africa. Her research looks at how coastal species adapt to climate change, and how to best use that information to guide conservation. She enjoys doing anything related to the ocean, from surfing and snorkelling to exploring the rocky shores!

\section{COLETTE BLYTH}

Colette Blyth is a Scottish Ph.D. student based at the University of Adelaide, South Australia. After falling in love with Australian wildlife, she decided on a Ph.D. project that uses genomics to make conservation recommendations for rare and threatened Australian plant species. Colette is very lucky, as this research project has led to many exciting adventures in the outback!

\section{LAURA D. BERTOLA}

Laura is a researcher at Copenhagen University, Denmark. She is interested in how data from DNA can be used to protect endangered species. For her Ph.D., she worked on lions, collecting all types of samples, even lion poop, which is a great source of DNA! Since it was not possible to travel much this year, Laura spent a lot of time photographing birds and insects in her backyard, which still feels like a little safari.

\section{MICHAEL BENJAMIN KANTAR}

Michael Benjamin Kantar is currently an assistant professor at the University of Hawai'i at Manoa. He received his Ph.D. in plant breeding and genetics from the University of Minnesota and did a post-doc at the University of British Columbia. He was a 2018 AAAS Leshner Leadership Institute Public Engagement Fellow. His research focuses on neo-domestication, crop wild relatives, food security, agroecology, and the genetic basis of local adaptation.

\section{HERNÁN E. MORALES}

Hernán Morales, originally from Mexico, is now a researcher in Denmark. He has studied the genetics of animals ranging from wasps to fish to snails to birds. Now he focuses on endangered birds, looking into genomes of museum samples, some over 100 years old, to compare them with birds of today. 

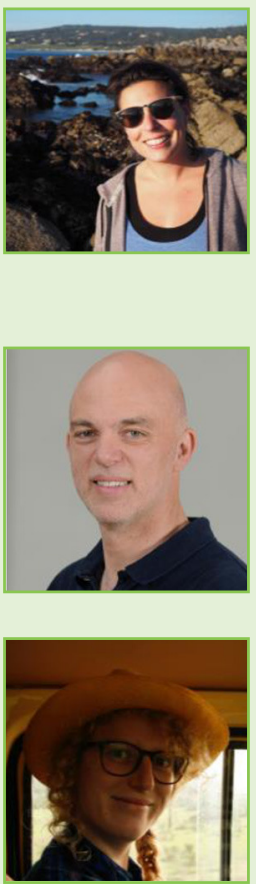

\section{CHLOÉ ORLAND}

Chloe Orland is a postdoctoral researcher at the University of California, Santa Cruz, USA. She is currently researching how environmental genomics can be used for conservation purposes, with a special focus on estimating genetic diversity in an endangered seashell called the black abalone. She generally loves working on all-things aquatic, from lakes and microbes to seaweed.

\section{GERNOT SEGELBACHER}

Gernot Segelbacher is professor in conservation genetics at the University of Freiburg, Germany. He studies endangered species (mostly birds) using molecular tools. Lately he is increasingly interested in providing this knowledge to the wider public. He also harvests many different apple and pear species each year.

\section{DEBORAH M. LEIGH}

Deborah Leigh is a researcher in Switzerland. She studies the genetics of endangered species and tries to figure out how to help them. She studied in the UK, Switzerland, and Canada. Her Ph.D. was on Alpine ibex and she now works on everything from puffins to trees. *deborahmleigh.research@gmail.com

${ }^{\dagger}$ These authors share first authorship

${ }^{\ddagger}$ GEOBON Genetic Composition Working Group member

\$Conservation Genetics Specialist Group-International Union for Conservation of Nature (IUCN) 